\title{
ОРГАНІЗАЦІЙНО-ПРАВОВЕ РЕГУЛЮВАННЯ ЗОВНІШНЬОЇ І ВНУТРІШНЬОЇ ТОРГІВЛІ ЛІКАРСЬКИМИ ЗАСОБАМИ В УКРАЇНІ ТА КРАЇНАХ ЄВРОПЕЙСЬКОГО СОЮЗУ
}

\section{Голубєва В. О.}

\section{ВСТУП}

3 огляду на важливість фармацевтичної сфери для життя і здоров'я людства взагалі (що підтверджено сучасними пандемічними обставинами) і обрання Україною даної галузі як однісї з перспективних і пріоритетних зокрема, вивчення умов (організація, здійснення і контроль) зовнішньої і внутрішньої торгівлі лікарськими засобами (їх обіг) $\epsilon$ актуальним i нагальним.

Розвиток фармацевтичного ринку (міжнародний i внутрішньодержавний) потребує відповідного «цивілізованого», дієвого та прогресивного регулювання, для збільшення експорту вітчизняних ліків необхідно вивчати вимоги інших країн, узагалі світової спільноти щодо особливостей іноземного/національного та «міжнародного / всесвітнього / універсального» нормативно-правового й організаційно-адміністративного регулювання та контролю за всіма складовими частинами процесу - від фармацевтичної розробки препарату до потрапляння його до дистриб'юторів, аптек і кінцевого споживача.

Державне регулювання фармацевтичного ринку у світі та в Україні обов'язково включає адміністративну (інституційна, організаційна) та регуляторну (правова, нормативна, джерельна) складові частини, що мають виконувати декілька завдань, а саме:

- гарантувати доступ на ринок ефективних, якісних та безпечних лікарських засобів;

- забезпечувати умови для функціонування на ринку максимального асортименту ліків, допущених в обіг, стимулювати водночас якомога швидшу появу інноваційних засобів лікування та профілактики захворювань;

- сприяти економічній доступності лікарських засобів для пацієнта тощо.

Основні функції регуляторної (організаційно-правова) політики держав щодо обігу лікарських засобів такі:

- створення та підтримка системи, що забезпечує дотримання вимог до обігу лікарських засобів на всіх етапах: розробки, виробництва, експорту/імпорту, транспортування, реалізації (внутрішньої торгівлі, 
зокрема за участю кінцевого споживача / пацієнта), споживання, утилізації тощо;

- ліцензування видів господарської діяльності у цій сфері;

- допуск на ринок (реєстрація) лікарських засобів;

- моніторинг безпечності (фармакологічний нагляд / контроль) і якості лікарських засобів на всіх етапах обігу;

- цінова політика та реімбурсація тощо.

Важливим аспектом належного функціонування світового i внутрішньодержавного ринків лікарняних препаратів $\epsilon$ забезпечення, гармонізація й уніфікація його нормативно-правового регулювання (багатостороннє, двостороннє та національне). Основною проблемою залишається гармонізація законодавства України, подолання його колізійності, забезпечення населення якісними ліками. У результаті укладання Угоди про асоціацію між Україною та Європейським Союзом (далі - СС) у 2014 р. ${ }^{1}$ (ст. ст. 220 і 222 якої стосуються лікарських засобів) національні нормативно-правові акти України потребують доопрацювання та гармонізації з відповідними директивами $С С$, крім того, не зайвим для національних експортерів буде й розуміння функціонування фармацевтичного ринку країн Свросоюзу.

\section{1. Загальна характеристика організаційно-правового регулювання} зовнішньої і внутрішньої торгівлі лікарськими засобами у країнах ЄС

На фармацевтичному ринку Свропейського Союзу функціонує багаторівнева система державного регулювання, що складається 3:

1) наднаціональних регуляторів - Свропейського агентства з лікарських засобів (European Medicines Agency - EMA) ${ }^{2}$ та Европейського директорату з якості лікарських засобів та охорони здоров'я (European Directorate for the Quality of Medicines \& Health Care - EDQM) ${ }^{3}$;

2) головних медичних агентств (Heads of Medicines Agencies - HMA), що становлять мережу національних компетентних органів, відповідальних за регулювання обігу лікарських засобів для застосування людиною і у ветеринарії на внутрішньому ринку $\mathrm{CC}$;

\footnotetext{
1 Угода про асоціацію між Україною, з однієї сторони, та Європейським Союзом, Європейським співтовариством з атомної енергії і їхніми державами-членами, з іншої сторони, від 27 червня 2014 р. URL: http://zakon2.rada.gov.ua/laws/show/984_a11 (дата звернення: 29.05.2020).

2 Європейське агентство 3 лікарських засобів (European Medicines Agency, EMA) : офіційний сайт. URL: https://www.ema.europa.eu/en (дата звернення: 29.05.2020).

${ }^{3}$ Європейський директорат з якості лікарських засобів та охорони здоров'я (European Directorate for the Quality of Medicines \& Health Care, EDQM) : офіційний сайт. URL: https://www.edqm.eu/ (дата звернення: 29.05.2020).

${ }^{4}$ Heads of Medicines Agencies (HMA) : official website. URL: https://www.hma.eu/ (дата звернення: 29.05.2020).
} 
3) національних регуляторних органів.

Вихід на ринок ЄС має відбуватися відповідно до централізованої процедури, обов'язкової для всіх інноваційних лікарських засобів, препаратів, вироблених із використанням біотехнологічних процесів, призначених для лікування орфанних захворювань, набутого імунодефіциту, онкологічних захворювань, нейродегенеративних розладів, цукрового діабету, аутоімунних захворювань та інших порушень роботи імунної системи, а також вірусних інфекцій. Інший шлях виходу на національні ринки деяких країн $\mathrm{CC} \mathrm{-} \mathrm{процедура} \mathrm{визнання.} \mathrm{У} \mathrm{разі}$ отримання допуску на ринок однієї країни за децентралізованою процедурою власник торгової ліцензії може подати заявку на проходження процедури взаємного визнання для виходу на ринки інших країн ЄС. Третій шлях - це національна (децентралізована) процедура, яка дає можливість входу на національний ринок (за процедурами, ухваленими національним регулятором). Кожна держава-член СС має власні процедури допуску препаратів на ринок, які дають змогу виводити на ринок лікарські засоби, що не підпадають під дію централізованої процедури (можуть не маркетуватися на всій території (С). Це так звані національні процедури, що не передбачають можливості використання процедури взаємного визнання (Mutual-recognition procedure ${ }^{5}$ ). Тобто в разі ухвалення рішення про вихід на інший ринок або ринки власник торгової ліцензії має подавати нову заявку на отримання дозволу на маркетинг. Регулювання та контроль ціноутворення, реімбурсації та закупівель у європейських країнах виконують інші агенції, аніж ті, що регулюють попередні етапи обігу лікарських засобів (клінічні дослідження, реєстрація тощо). В Україні це покладено на Міністерство охорони здоров'я (далі- МО3)

Отже, як уже зазначалося, «загальноєвропейська регуляторна рамка» складається із двох основних елементів:

1) Європейське агентство 3 лікарських засобів (далі - ЕМА) ${ }^{7} \epsilon$ центральним органом Європейської мережі 3 контролю за обігом лікарських засобів, що об'єднує діяльність 40 національних регуляторних агентств, Європейської комісії, Європейського парламенту, а також децентралізованих європейських агентств. Головне завдання ЕМА - захист здоров'я населення і тварин за допомогою оцінки та контролю лікарських засобів для людини i ветеринарних препаратів. Агентство несе

\footnotetext{
${ }^{5}$ URL: https://ec.europa.eu/health/authorisation-procedures-national_en ; URL: https://www.ema.europa.eu/ en/glossary/mutual-recognition.

${ }_{6}$ Міністерство охорони здоров’я України (MO3) : Щфіційний сайт. URL: https://moz.gov.ua/proministerstvo (дата звернення: 29.05.2020).

${ }^{7}$ Європейське агентство 3 лікарських засобів (European Medicines Agency, EMA) : офіційний сайт. URL: https://www.ema.europa.eu/en (дата звернення: 29.05.2020).
} 
відповідальність за наукову оцінку (експертизу) заявок на отримання дозволу на маркетинг лікарських засобів для застосування людиною та у ветеринарії в СС за централізованою процедурою (у роботі ЕМА задіяні майже 4,5 тис. експертів). ЕМА відповідає за координацію системи моніторингу безпеки - системи фармакологічного нагляду, відповідає за координацію перевірок, які проводяться для гарантування відповідності заявників вимогам GMP, GCP, GLP і фармакологічного нагляду, веде базу даних лікарських засобів, зареєстрованих за централізованою процедурою.

2) Європейський директорат з якості лікарських засобів та охорони здоров'я (далі - EDQM) ${ }^{8}$ - інститут Ради Європи, що забезпечує захист суспільної охорони здоров'я шляхом розроблення, підтримки впровадження і контролю застосування стандартів якості для гарантування безпечності лікарських засобів та їх безпечного застосування. EDQM є видавцем Європейської фармакопеї, що затверджує стандарти якості лікарських засобів. EDQM підпорядкована Мережа офіційних лабораторій із контролю за лікарськими засобами (Network of official medicines control laboratories (далі - OMCLs) $)^{9}$. OMCLs надає підтримку регуляторним органам у сфері контролю якості лікарських засобів, маркетованих на європейському ринку, та здійснює не залежний від компаній-виробників контроль якості препаратів.

Так, «Національна регуляторна рамка» Польщі складається 3 таких елементів:

1) Управління $з$ реєстрації лікарських засобів, виробів медичного призначення та біоцидів (Urzad Rejestracji Produktyw Leczniczych, Wyrobyw Medycznych i Produktyw Biobyjczych) - відповідає за реєстрацію препаратів;

2) Інститут лікарських засобів (Instytut Lekyw) із підпорядкованою йому мережею національних лабораторій із контролю якості лікарських засобів (Official Medicines Control Laboratories Network) - відповідає за оцінку якості, профілю безпечності і терапевтичної ефективності лікарських засобів;

3) Головна фармацевтична інспекція (Giywny Inspektorat Farmaceutyczny) відповідає за перевірки препаратів, що перебувають в обігу на ринку, та контроль умов виробництва;

\footnotetext{
${ }^{8}$ Європейський директорат з якості лікарських засобів та охорони здоров'я (European Directorate for the Quality of Medicines \& Health Care, EDQM) : офіційний сайт. URL: https://www.edqm.eu/ (дата звернення: 29.05.2020).

${ }_{9}$ Мережа офіційних лабораторій з контролю за лікарськими засобами (Network of official medicines control laboratories, OMCLs). URL: https://www.edqm.eu/sites/default/files/brochure_omcl_double_page_ web.pdf (дата звернення: 29.05.2020).
} 
4) Національний підрозділ з моніторингу побічних реакцій на лікарські засоби Польщі (Polish National Unit for Monitoring Adverse Drug Reactions) - відповідає за контроль профілю безпечності зареєстрованих лікарських засобів на післяреєстраційному етапі.

Незалежно від «інституційної рамки» (один чи декілька органів) у країнах СС існують і міністерства, відповідальні за охорону здоров'я, однак їхні повноваження зводяться до формування загальної державної політики у фармацевтичній сфері. I множинна модель регулювання (полісистемна, як у СС), і модель одного органу (сингулярна, наприклад, України) мають свої переваги і недоліки. За множинної моделі перевагою можна визнати чіткий розподіл функцій, більшу спеціалізацію (а отже, i вищу професійність) органів, а за умови забезпечення їхньої реальної незалежності одне від одного - більший рівень страхування від помилки та можливість іiі виправлення на наступному етапі контролю, який здійснюється іншим органом. Водночас більш складний процес управління та координації роботи цих органів, можливе дублювання функцій, додається бюрократичний складник у відносинах, що уповільнює процес організації регуляторної та наглядово-контрольної роботи, увхалення управлінських рішень. За моделі одного органу підвищується оперативність роботи (внутрішні процедури завжди швидші, ніж зовнішні) та скорочуються і спрощуються бюрократичні операції, однак зростає вірогідність того, що допущені помилки не будуть виявлені (через відсутність додаткового контролю) ${ }^{10}$. Головне, що об'єднує і множинну модель, і модель одного органу - це набір їхніх обов'язкових функцій (ліцензійно-дозвільні, експертні та контроль якості).

Торгівля між державами-членами $€ C$ відбувається в межах внутрішнього ринку $\mathrm{CC}$, iї основними принципами $\epsilon$ вільне переміщення товарів, послуг капіталу й осіб. Загальні правила імпорту («Регламент імпорту») поширюються на товари, які імпортуються, товари, що походять із третіх країн, за винятком текстильних виробів, на які поширюються спеціальні загальні правила, та продукти, що походять 3 окремих третіх країн (Регламент ЄС від 29 квітня 2015 р. № 2015/755 ${ }^{11}$ ). Відповідно до загальних правил імпорту, товари можуть вільно імпортуватися до $\mathrm{CC}$, отже, не підлягають кількісним обмеженням, без шкоди для захисних заходів, які можуть бути вжиті в рамках регулювання імпорту. Заходи захисту можуть бути застосовані в разі імпорту до $С С$ у значно збільшеній

10 IMS. World Review 2014. URL: https://www.reportlinker.com/p01593816/IMS-World-ReviewExecutive.html (дата звернення: 29.05.2020).

${ }^{11}$ Regulation (EU) 2015/755 of the European Parliament and of the Council of 29 April 2015 on common rules for imports from certain third countries. URL: https://eur-lex.europa.eu/legal- content/en/TXT/ ?uri=CELEX:32015R0755 (дата звернення: 29.05.2020). 
кількості та/або таких умовах, що можуть завдати серйозної шкоди національним виробникам Свросоюзу.

На сучасному етапі нормативно-правове забезпечення/регулювання обігу лікарських засобів у СС здійснюється на підставі: Директиви 2001/83 «Кодекс Союзу про лікарські препарати, призначені для застосування людиною» від 6 листопада 2001 p. $^{12}$; Директиви 2005/28 ${ }^{13}$ «Про впровадження принципів належної клінічної практики $<\ldots .>$ » від 8 квітня 2005 р.; Директиви 2001/20/СС «Про клінічні дослідження <..>» від 4 квітня 2001 p. $^{14}$ та ін.

У ЄС практично існує чотири різні процедури отримання дозволу на продаж лікарських засобів (які можуть бути пов'язаними), зокрема: централізована процедура, децентралізована процедура, процедура взаємного визнання, національна процедура кожної окремої державичлена.

Централізована процедура доступна для обмеженого кола товарів (продукції, зокрема, лікарських засобів), перелічених у Регламенті (СС) 726/2004 від 31 березня 2004 р. про дозвільну систему та нагляд за лікарськими засобами та створення Європейського агентства 3 лікарських засобів (Регламент ЕМА) ${ }^{15}$.

Директива 2001/83 «Кодекс Союзу про лікарські препарати, призначені для застосування людиною» від 6 листопада 2001 p. $^{16} \epsilon$ правовою підставою як для взаємного визнання, так i для децентралізованих процедур. Вони створені для того, щоб надати можливість заявникам отримати державні дозволи в кількох країнах-членах ЄС швидше та/або 3 меншим адміністративним навантаженням, ніж у разі, коли кожна заявка буде розглянута повністю окремо в кожній країні-члені. Вони відрізняються від централізованого дозволу, оскільки кожна країна-член

12 Directive 2001/83/EC of the European Parliament and of the Council of 6 November 2001 on the Community code relating to medicinal products for human use. URL: https://eur-lex.europa.eu/legalcontent/en/ALL/?uri=CELEX\%3A32001L0083 (дата звернення: 29.05.2020).

${ }^{13}$ Commission Directive 2005/28/EC of 8 April 2005 laying down principles and detailed guidelines for good clinical practice as regards investigational medicinal products for human use, as well as the requirements for authorisation of the manufacturing or importation of such products (Text with EEA relevance). URL: https://eur-lex.europa.eu/legal-content/EN/ALL/?uri=CELEX\%3A32005L0028 (дата звернення: 29.05.2020).

${ }^{14}$ Directive 2001/20/EC of the European Parliament and of the Council of 4 April 2001 on the approximation of the laws, regulations and administrative provisions of the Member States relating to the implementation of good clinical practice in the conduct of clinical trials on medicinal products for human use. URL: eurlex.europa.eu/legal-content/EN/TXT/?uri=CELEX\%3A32001L0020 (дата звернення: 29.05.2020).

${ }^{15}$ Regulation (EC) № 726/2004 of the European Parliament and of the Council of 31 March 2004 laying down Community procedures for the authorisation and supervision of medicinal products for human and veterinary use and establishing a European Medicines Agency (Text with EEA relevance). URL: https://eurlex.europa.eu/legal-content/EN/TXT/?uri=CELEX\%3A32004R0726 (дата звернення: 29.05.2020).

${ }^{16}$ Directive 2001/83/EC of the European Parliament and of the Council of 6 November 2001 on the Community code relating to medicinal products for human use. URL: https://eur-lex.europa.eu/legalcontent/en/ALL/?uri=CELEX\%3A32001L0083 (дата звернення: 29.05.2020). 
має/видає власну авторизацію, а це означає, що звіти про фармакологічні наслідки та варіанти дозволів мають оформлюватися окремо в кожній державі-члені СС.

3 метою збільшення доступності лікарських засобів дозволяється, за відсутності ліцензії на продаж або заявки на отримання такої ліцензії лікарського засобу, використовувати ліцензію, яка вже була видана в іншій державі-члені, що дозволила випустити на ринок цей лікарський засіб 3 обгрунтованих обставин для поліпшення громадського здоров’я («взаємне визнання»). Кожна держава-член $Є С$ може запроваджувати власний механізм для реалізації означеної процедури, а ії компетентний орган зобов'язаний повідомляти при такі випадки Європейське агентство 3 лікарських засобів (ЕМА). Загальнодоступний реєстр лікарських засобів, дозволених для обігу на ринку, міститься на сайті ЕМА ${ }^{17}$.

Крім того, коли неможливо надати повні дані за звичайних умов використання лікарських засобів, ліцензія може бути надана за «виняткових обставин» (ст. 14 Регламенту (СС) 726/2004 від 31 березня 2004 p. $^{18}$ ), у разі наявності однієї із зазначених причин, пов'язаних із лікарськими засобами або інформацією про них:

- занадто рідке їх використання;

- сучасний стан наукових знань не дозволяє ії збирати;

- було б узагалі неетично збирати дані.

Дозволи, надані у «виняткових випадках», відрізняються від «умовних дозволів», для яких дані будуть надані, але не можуть бути надані в найближчому майбутньому.

Наприклад, власник оптової дилерської ліцензії має право паралельно експортувати товар з однієї держави-члена ЄС, де існує ліцензія на продаж для лікарського засобу, в іншу державу-член $\mathrm{CC}$, де існує ліцензія на продаж для подібного лікарського засобу. Якщо оригінальний виробник лікарського засобу володіє правами інтелектуальної власності, включаючи права на торговельну марку, тоді їм не дозволяється реалізовувати свої права на протидію імпорту іншому, який був законним чином розміщений на ринку в іншій державі-члені, або за згодою власника цього права. Унаслідок культурних, зокрема мовних, відмінностей продукти, якими паралельно торгують, зазвичай перепаковуються. Такі заходи були предметом значної кількості судових позовів, результат яких, по суті,

\footnotetext{
${ }^{17}$ Свропейське агентство 3 лікарських засобів (European Medicines Agency, EMA) : офіційний сайт. URL: https://www.ema.europa.eu/en (дата звернення: 29.05.2020).

${ }^{18}$ Regulation (EC) № 726/2004 of the European Parliament and of the Council of 31 March 2004 laying down Community procedures for the authorisation and supervision of medicinal products for human and veterinary use and establishing a European Medicines Agency (Text with EEA relevance). URL: https://eurlex.europa.eu/legal-content/EN/TXT/?uri=CELEX\%3A32004R0726 (дата звернення: 29.05.2020).
} 
полягає в тому, що власник торговельної марки не може використовувати своє право для запобігання перепакування продукту, імпортованого паралельно, коли (СОМ (2003) 839 $\left.{ }^{19}\right)$ :

- використання права власності на торговельну марку власником, беручи до уваги систему маркетингу, яку вона прийняла, сприятиме артикційному розподілу ринків між державами-членами;

- перепакування не може негативно впливати на вихідний стан продукту;

- назва нового пакувальника вказана на новій упаковці;

- презентація упакованого лікарського засобу не спричиняє шкоди репутації торговельної марки та його власника;

- власник торговельної марки отримує попереднє повідомлення перед тим, як упакований продукт буде проданий.

Європейський суд підтвердив, що власник оригінальної товарної марки має право заперечувати проти продовження маркетингу паралельного імпортного лікарського засобу, на якому його торговельна марка була знову підтверджена, якщо власник товарного знаку випустив товар на ринок того самого об’єму та розміру пакетів, як і упакований продукт, тому що це доводить, що перепакування не є необхідним для запобігання штучному розподілу ринку (Ferring Lægemidler A / S та Orifarm A / S (C-297/15) ${ }^{20}$ ).

\section{2. Деякі особливості адміністративно-правового регулювання /} забезпечення національного ринку лікарських засобів України

Основу організаційно-правового регулювання зовнішньої торгівлі закріплено у ст. 263 Господарського кодексу України ${ }^{21}$, крім того, обіг лікарських засобів має деякі особливості, отже, i низку спеціальних нормативно-правових актів, які визначають / закріплюють умови їх здійснення (наприклад, постанова Кабінету Міністрів України № 929 від 30 листопада 2016 р. «Про затвердження Ліцензійних умов провадження господарської діяльності 3 виробництва лікарських засобів, оптової та роздрібної торгівлі лікарськими засобами, імпорту лікарських засобів (крім активних фармацевтичних інгредієнтів)» ${ }^{22}$ ).

\footnotetext{
${ }^{19}$ Commission Communication on parallel imports of proprietary medicinal products for which marketing authorisations have already been granted : Commission of the European Communities of 30.12.2003 COM (2003) 839 final, Brussels, (COM (2003) 839). URL: https://ec.europa.eu/health/sites/health/files/ files/eudralex/vol-1/com_2003_839/com_2003_839_en.pdf (дата звернення: 29.05.2020).

${ }^{20}$ Case C-297/15: Request for a preliminary ruling from the Sø- og Handelsretten (Denmark) lodged on 18 June 2015 - Ferring Lægemidler A/S, acting on behalf of Ferring B.V. v Orifarm A/S. URL: https://eur-lex.europa.eu/legal-content/EN/TXT/?uri=CELEX:62015CN0297 (дата звернення: 29.05.2020).

${ }^{21}$ Господарський кодекс України : Закон від 16 січня 2003 р. № 436-IV. URL: https://zakon.rada.gov.ua/ laws/show/436-15 (дата звернення: 29.05.2020).

22 Про затвердження Ліцензійних умов провадження господарської діяльності 3 виробництва лікарських засобів, оптової та роздрібної торгівлі лікарськими засобами, імпорту лікарських засобів
} 
Ліцензійні умови містять вичерпний перелік обов'язкових вимог для виконання ліцензіатом та вичерпний перелік документів, що додаються до заяви про отримання ліцензії для здійснення господарської діяльності 3 виробництва лікарських засобів, оптової, роздрібної торгівлі лікарськими засобами, імпорту лікарських засобів (крім активних фармацевтичних інгредієнтів). Дія цих Ліцензійних умов поширюється на всіх зареєстрованих в установленому законодавством України порядку суб'єктів господарювання, зокрема на юридичних осіб незалежно від їхньої організаційно-правової форми та форми власності, а також фізичних осіб-підприємців. Тобто із 2016 р. в Україні запрацювала система, яка дозволила проводити контроль дистриб'ютора, який імпортує лікарські засоби на територію України і здійснює передачу партій товару аптекам i аптечним складам. В основу державного контролю в зазначеній сфері покладено низку вимог до здійснення господарської діяльності 3 лікарськими засобами:

- забороняється торгівля лікарськими засобами: неякісними; термін придатності яких минув; за відсутності сертифіката якості, що видається виробником;

- заборонена торгівля лікарськими засобами, виготовленими аптекою 3 порушеннями умов виробництва;

- торгівля лікарськими засобами здійснюється лише через аптеки, аптечні бази (склади);

- аптека, аптечна база (склад) функціонують з дозволу і під контролем державних органів;

- аптека, аптечна база (склад) повинні пройти державну акредитацію протягом року з дати отримання ліцензії.

Суб'єкт господарювання повинен забезпечити:

- відповідність матеріально-технічної бази вимогам нормативних документів щодо виробництва, зберігання, контролю якості, торгівлі лікарськими засобами;

- дотримання вимог законодавства щодо якості лікарських засобів під час виробництва, транспортування, зберігання та торгівлі;

- наявність підрозділу чи фахівця з контролю якості лікарських засобів або наявності договору 3 акредитованою лабораторією 3 аналізу якості лікарських засобів;

- наявність плану термінових дій щодо зупинення виробництва, торгівлі, вилучення з торгівлі лікарських засобів і вжиття заходів для повернення продавцю (виробнику) лікарських засобів або їх знищення, утилізації;

(крім активних фармацевтичних інгредієнтів) : постанова Кабінету Міністрів України від 30 листопада 2016 p. № 929. URL: http://zakon.rada.gov.ua/laws/show/929-2016-\%D0\%BF (дата звернення: 29.05.2020). 
- зберігання та надання контрольним органам для перевірок документів, що фіксують: закупівлю, виробництво, зберігання, транспортування, знищення або утилізацію лікарських засобів.

Але, на відміну від України, у СС процедури та правила щодо торгівлі лікарськими засобами дещо відрізняються.

Доктринальна юридична наука під час розгляду різновидів правового регулювання особливу увагу приділяє дозвільному типу, в основі якого загальна заборона. У законодавстві України дозвільний тип правового регулювання асоціюється зазвичай із ліцензуванням (певного виду господарської діяльності чи ліцензування виду продукції/товару). Зазвичай ідеться лише про здійснення господарської діяльності, а інші види дозвільного типу правового регулювання залишилися поза увагою, це вимагає уніфікації дозвільних процедур із метою подальшої імплементації законодавства ЄС у сфері охорони здоров'я.

Згідно зі ст. 7 Закону України «Про ліцензування видів господарської діяльності», у сфері охорони здоров'я ліцензуванню підлягають такі види господарської діяльності: 1) виробництво лікарських засобів, оптова та роздрібна торгівля лікарськими засобами, імпорт лікарських засобів (крім активних фармацевтичних інгредієнтів) - 3 урахуванням особливостей, визначених Законом України «Про лікарські засоби» (п. 10); 2) медична практика (п. 15) 23.

Щодо цього, застосовуючи термінологію лише до діяльності щодо обігу лікарських засобів, правознавці зазначали, що, ураховуючи вимоги законодавства України щодо обігу лікарських засобів, можна визначити такі типи регулювання: загальнодозвільний, в основу якого покладено загальний дозвіл на виконання дій, які не заборонені законодавством (наприклад, дозвіл на реалізацію безрецептурних лікарських засобів через загальну торговельну мережу); дозвільний, в основі якого лежить загальна заборона, що дозволяє суб'єктам господарювання здійснювати тільки ті дії, які дозволені законодавством (наприклад, реалізація в Україні лише зареєстрованих лікарських засобів за наявності сертифіката якості). I справді, зазначене твердження $\epsilon$ актуальним лише в контексті отримання права щодо окремих операцій під час здійснення господарської діяльності окремими суб'єктами господарювання. Проте не йдеться про виконання певних дій або використання прав, безпосередньо не пов'язаних із застосуванням положень Закону України «Про ліцензування видів господарської діяльності». Як наслідок, цілком слушним є твердження, що загальними засобами регулювання обігу лікарських препаратів необхідно

\footnotetext{
${ }^{23}$ Про ліцензування видів господарської діяльності : Закон України від 2 березня 2015 р. № 222-VIII. URL: https://zakon.rada.gov.ua/laws/show/222-19 (дата звернення: 29.05.2020).
} 
визнати: позитивне зобов'язання - покладення на суб'єктів господарювання, які здійснюють обіг лікарських засобів, обов'язків щодо активної поведінки, тобто реєстрації лікарських засобів, отримання спеціального дозволу (ліцензіі) на здійснення окремого виду виробничої діяльності, дотримання норм стандартизації та сертифікації, покликаних забезпечити якість лікарських засобів; дозвільну систему - надання суб'єктам господарювання права на власні активні дії після отримання спеціального дозволу (ліцензії) у межах цього дозволу, тобто дії, пов'язані 3 виробництвом, увезенням, оптовою або роздрібною реалізацією лікарських засобів; систему нагляду та заборони - покладення на суб'єктів господарювання обов'язків утримуватися від здійснення дій під наглядом державних органів контролю за обігом лікарських засобів.

У цьому контексті не зовсім актуальним є використання такого поняття, як «торгова ліцензія на лікарський засіб», окремі експерти зазначений термін уважають аналогічним такому поняттю, як «сертифікація лікарських засобів», їх реєстрація. Хоча існує й інша думка, згідно з якою державна реєстрація лікарських засобів в Україні надає право на їх використання та реалізацію лише на території України. У країнах ЄС торгова ліцензія, крім цих двох понять, включає дозвіл на імпорт лікарського засобу, тобто надає дозвіл на застосування в усіх країнах ЄС. Крім того, відповідно до ст. 6 Директиви 2001/83 «Кодекс Союзу про лікарські препарати, призначені для застосування людиною» від 6 листопада 2001 p. $^{24}$, жоден лікарський препарат не може бути розміщеним на ринку держави-члена $\mathrm{CC}$, якщо на нього не видана торгова ліцензія компетентним уповноваженим органом цієї країни. У країнах СС ліцензування/видача дозволів на продаж/маркетинг, поряд iз ліцензуванням виробництва, дозволяє лікам потрапити в обіг. Отже, у такому разі йдеться про наявність дозволу у вигляді торгової ліцензії для розміщення на ринку ЄС лікарських препаратів.

Відповідно до ч. 1 ст. 9 Закону України «Про лікарські засоби» ${ }^{25}$, лікарські засоби допускаються до застосування в Україні після їх державної реєстрації, крім випадків, передбачених законодавством. А якщо проаналізувати юридичний зміст терміна «державна реєстрація» визначений законодавчими актами порядок внесення уповноваженими державними органами певних відомостей до державних реєстрів, то зрозуміло, що йдеться лише про облік. Це підтверджує і додаткова вимога

\footnotetext{
${ }^{24}$ Directive 2001/83/EC of the European Parliament and of the Council of 6 November 2001 on the Community code relating to medicinal products for human use. URL: https://eur-lex.europa.eu/legalcontent/en/ALL/?uri=CELEX\%3A32001L0083 (дата звернення: 29.05.2020).

25 Про лікарські засоби : Закон України від 4 квітня 1996 р. № 123/96-BP. URL: https://zakon.rada.gov.ua/laws/show/123/96-\%D0\%B2\%D1\%80 (дата звернення: 29.05.2020).
} 
щодо розміщення лікарських засобів на ринку України (ч. 2 ст. 20 Закону України «Про лікарські засоби») ${ }^{26}$ : «Реалізація лікарських засобів здійснюється лише за наявності сертифіката якості, що видається виробником (для імпортованих лікарських засобів - імпортером (виробником або особою, що представляє виробника лікарських засобів на території України)». Отже, існуюча в Україні процедура правової легітимації лікарських засобів на внутрішньому ринку не лише не відповідає нормам $€ \mathrm{C}$, а і $є$ громіздкою і недосконалою у правовому значенні та складається із процедури державної реєстрації лікарських препаратів і процедури отримання сертифіката якості виробника. У даному разі йдеться не лише про уніфікацію термінології допуску лікарських препаратів на ринок України, а й про спрощення дозвільного типу правового регулювання обігу лікарських засобів та їх допуску на ринок лише шляхом отримання торгової ліцензії. Для синхронізації системи контролю лікарських засобів в Україна i світі, а також уніфікації документів для імпорту варто видалити норму щодо необхідності надання локального сертифіката якості, відповідно до вимог Держлікслужби ${ }^{27}$.

Тобто в Україні ліцензування існує паралельно 3 реєстрацією. Ліцензування виробництва й імпорту лікарських засобів, оптової та роздрібної торгівлі лікарськими засобами здійснюється відповідно до законів України «Про лікарські засоби» ${ }^{28}$ та «Про ліцензування видів господарської діяльності» ${ }^{29}$. В Україні строк ухвалення рішення про видачу ліцензії досить короткий -10 робочих днів із дня одержання органом ліцензування заяви про отримання ліцензії. Вартість офіційних платежів за отримання дозвільного документа в Україні становить одну мінімальну заробітну плату (станом на початок 2020 р. -4723 грн) $)^{30}$. У державах-членах $Є С$ цей строк становить 90 днів, а вартість значно більша (наприклад, у Польщі - 8000 злотих, або приблизно 45000 грн.).

Наступним дозвільним аспектом правового регулювання у сфері охорони здоров'я можна вважати ліцензування професії медичних та фармацевтичних працівників, про яке іноді згадують організатори сфери охорони здоров'я в контексті реформ. Індивідуальне ліцензування всіх без

26 Про лікарські засоби : Закон України від 4 квітня 1996 р. № 123/96-BP. URL: https://zakon.rada.gov.ua/laws/show/123/96-\%D0\%B2\%D1\%80 (дата звернення: 29.05.2020).

27 Про затвердження Порядку встановлення заборони (тимчасової заборони) та поновлення обігу лікарських засобів на території України : наказ MO3 України від 22 листопада 2011 р. № 809. URL: https://zakon.rada.gov.ua/laws/show/z0126-12 (дата звернення: 29.05.2020).

28 Про лікарські засоби : Закон України від 4 квітня 1996 р. № 123/96-BP. URL: https://zakon.rada.gov.ua/laws/show/123/96-\%D0\%B2\%D1\%80 (дата звернення: 29.05.2020).

${ }_{29}$ Про ліцензування видів господарської діяльності : Закон України від 2 березня 2015 р. № 222-VIII. URL: https://zakon.rada.gov.ua/laws/show/222-19 (дата звернення: 29.05.2020).

${ }^{30}$ Про Державний бюджет України на 2020 р. : Закон Українивід 14 листопада 2019 р. № 294-IX. URL: https://zakon.rada.gov.ua/laws/show/294-20 (дата звернення: 29.05.2020). 
винятку лікарів (ветеринарів також) - світова практика. Так, у більшості розвинених країн усі медичні професії є регульованими, отже, кожен лікар повинен підтвердити свою кваліфікацію за допомогою отримання медичної ліцензії для здійснення професійної діяльності. У пп. 14.1.226 п. 14.1 ст. 14 Податкового кодексу України ${ }^{31}$ фактично йдеться про право зайняття незалежною професійною діяльністю, зокрема й лікарями, за умови, що така особа не є працівником або фізичною особою-підприємцем та використовує найману працю не більше ніж чотирьох фізичних осіб. Ліцензування професійної діяльності медичних та фармацевтичних працівників необхідно також розглядати в контексті діяльності саморегульованих та/або самоврядних організацій. Тобто йдеться не про здійснення господарської діяльності, а про отримання права на професійну діяльність як дозвільного типу правового регулювання. Запровадження ліцензування як дозвільного типу правового регулювання в такій формі 3 метою уніфікації термінології потребує внесення змін і доповнень у Закон України «Про лікарські засоби», Основи законодавства України про охорону здоров'я та Господарський кодекс України (ст. 12).

Лікарські засоби повинні пройти державну реєстрацію в $\mathrm{MO}^{32}$ для продажу на території України ${ }^{33}$. Це зобов'язання однаково застосовується до місцевих та імпортних лікарських засобів (за винятком обмеженого числа випадків, наприклад, ліків, вироблених в аптеках). Для засвідчення державної реєстрації лікарського засобу МО3 видає свідоцтво про реєстрацію (ліцензія на реєстрацію) лікарського засобу, термін дії якого становить п'ять років і може бути поновлений після звернення до $\mathrm{MO}^{34}$.

Спрощена процедура реєстрації застосовується до ліків із країн із жорсткою регуляторною політикою. Щоб отримати право на спрощену процедуру, потрібно зареєструвати препарат у країні із жорсткою регуляторною політикою для використання в такій країні. До таких країн належать Сполучені Штати Америки, Швейцарія, Японія, Австралія, Канада, а також країни-члени СС, але за умови, що ліки було зареєстровано компетентним органом СС за централізованою процедурою.

\footnotetext{
31 Податковий кодекс України : Закон від 2 грудня 2010 p. № 2755-VI. URL: https://zakon.rada.gov.ua/laws/show/2755-17 (дата звернення: 29.05.2020).

32 Про затвердження Положення про Міністерство охорони здоров’я України : постанова Кабінету Міністрів України від 25 березня 2015 р. № 267. URL: https://zakon.rada.gov.ua/laws/show/267-2015\%D0\%BF (дата звернення: 29.05.2020).

33 Про затвердження Порядку державної реєстрації (перереєстрації) лікарських засобів і розмірів збору за їх державну реєстрацію (перереєстрацію) : постанова Кабінету Міністрів України від 26 травня 2005 p. № 376. URL: https://zakon.rada.gov.ua/laws/show/376-2005-\%D0\%BF (дата звернення: 29.05.2020).

34 Про затвердження Порядку проведення експертизи реєстраційних матеріалів на лікарські засоби, що подаються на державну реєстрацію (перереєстрацію), а також експертизи матеріалів про внесення змін до реєстраційних матеріалів протягом дії реєстраційного посвідчення : наказ МОЗ України від 26 серпня 2005 р. № 426. URL: https://zakon.rada.gov.ua/laws/show/z1069-05 (дата звернення: 29.05.2020).
} 
У спрощеній процедурі, крім іншого, передбачається зниження вимог до документації та термінів ухвалення регуляторних рішень. Також це $\epsilon$ додатковою перепоною щодо реєстрації лікарських засобів європейської якості, бо немає жодної необхідності контролювати документацію національними (локальними) контролюючими органами, якщо вони пройшли централізовану процедуру у FDA та EMEA.

Головними напрямами розвитку ліцензування у фармацевтичній та медичній галузях протягом останніх років було посилення жорсткості умов регулювання та їх наближення до стандартів СС. Україна пішла шляхом тих європейських країн, які відмовилися від лібералізації і посилили державний контроль за операторами фармацевтичного ринку. Із 2012 р. Держлікслужба України (приєдналася в січні 2011 p..$^{35}$ ) стала повноправним членом Міжнародної системи співробітництва фармацевтичних інспекцій (Pharmaceutical Inspection Cooperation Scheme - PIC/S), що об'єднує $53^{36}$ країни із жорсткою регуляторною системою. Це забезпечує активну та конструктивну міжнародну співпрацю України у сфері GMP, інспектування та ліцензування, а також у запровадженні міжнародної системи стандартів для взаємного визнання результатів інспектувань. У результаті Державною Службою України 3 лікарських засобів та контролю за наркотиками сформовано GMP- та GDP-інспекторат ${ }^{37}$.

Найголовнішою позитивною зміною останніх років було запровадження вимог належної виробничої практики як обов'язкової вимоги для виробництва й імпорту лікарських засобів. 3 метою пришвидшення процесу забезпечення пацієнтів якісними i життєво необхідними лікарськими засобами необхідно внести зміни до наказу МОЗ № 1130 «Про затвердження Порядку проведення підтвердження відповідності умов виробництва лікарських засобів вимогам належної виробничої практики» від 27 грудня 2012 p. $^{38}$ щодо видачі міжнародного сертифіката, якщо країна входить до PICS, а в іншому випадку - необхідно проходити спеціалізовану експертизу. У 2014 р. наказом МОЗ затверджена настанова «Лікарські засоби. Належна практика дистрибуції. СТ-Н МОЗУ 42-5.0:

\footnotetext{
35 Міжнародна система співробітництва фармацевтичних інспекцій (Pharmaceutical Inspection Cooperation Scheme, PIC/S) : офіційний сайт. URL: https://www.picscheme.org/en/members?paysselect=UA (дата звернення: 29.05.2020).

36 Міжнародна система співробітництва фармацевтичних інспекцій (Pharmaceutical Inspection Cooperation Scheme, PIC/S) : офіційний сайт. URL: https://www.picscheme.org/en/members (дата звернення: 29.05.2020).

37 Державна служба України з лікарських засобів та контролю за наркотиками (Держлікслужба) : офіційний сайт. URL: http://dls.gov.ua/ (дата звернення: 29.05.2020).

38 Про затвердження Порядку проведення підтвердження відповідності умов виробництва лікарських засобів вимогам належної виробничої практики : наказ MO3 України від 27 грудня 2012 р. № 1130. URL: https://zakon.rada.gov.ua/laws/show/z0133-13 (дата звернення: 29.05.2020).
} 
2014» ${ }^{39}$, гармонізована 3 оновленою редакцією GDP ЄC. Зміни до національної настанови із GMP вносяться регулярно, що дає змогу актуалізувати їх згідно зі змінами європейських стандартів. Отже, вимоги GDP стають обов'язковими і для оптової ланки реалізації лікарських засобів в Україні.

Деякі зміни мали неоднозначний характер. Наприклад, ліцензування імпорту в СС відповідно до Директиви 2001/83 «Кодекс Союзу про лікарські препарати, призначені для застосування людиною» від 6 листопада 2001 p. $^{40}$ не передбачає окремої ліцензії на імпорт лікарських засобів, вона $є$ частиною ліцензії на виробництво. Замість неї імпортери зобов'язані отримувати ліцензію на провадження господарської діяльності 3 імпорту лікарських засобів. У державах ЄС одна юридична особа часто бере на себе дві функції - імпортера та власника реєстраційного посвідчення. Запровадження цієї регуляторної норми спричинило законодавчі колізії, але не підвищило відповідальності за якість ліків, що ввозяться.

Важлива роль у забезпеченні якості лікарських засобів належить постреєстраційному контролю та нагляду, що включає контроль якості лікарських засобів на етапі ввезення на митну територію України і під час оптової та роздрібної торгівлі, що здійснюються Держлікслужбою ${ }^{41}$, а також фармакологічний нагляд, координацію якого забезпечує Державний експертний центр МО3 України ${ }^{42}$. У результаті контролю неякісні, незареєстровані або фальсифіковані серії лікарського засобу забороняються та вилучаються з обігу, а в окремих випадках забороняється застосування всіх серій лікарського засобу шляхом припинення дії реєстраційного посвідчення.

Окремо необхідно звернути увагу на Міністерство охорони здоров'я України, до основних повноважень якого у сфері обігу лікарських препаратів, виробів медичного призначення та функціонування фармацевтичного ринку віднесено ${ }^{43}$ :

\footnotetext{
39 Лікарські засоби. Належна практика дистрибуції. СТ-Н МОЗУ 42-5.0: 2014 : настанова МО3 України. Стандарт. Київ : Міністерство охорони здоров'я України, 2014. 51 c. URL: http://dls.gov.ua/wpcontent/uploads/2019/06/\%D0\%9D\%D0\%B0\%D0\%BB\%D0\%B5\%D0\%B6\%D0\%BD\%D0\%B0$\% \mathrm{D} 0 \% \mathrm{BF} \% \mathrm{D} 1 \% 80 \% \mathrm{D} 0 \% \mathrm{~B} 0 \% \mathrm{D} 0 \% \mathrm{BA} \% \mathrm{D} 1 \% 82 \% \mathrm{D} 0 \% \mathrm{~B} 8 \% \mathrm{D} 0 \% \mathrm{BA} \% \mathrm{D} 0 \% \mathrm{~B} 0-$ \%D0\%B4\%D0\%B8\%D1\%81\%D1\%82\%D1\%80\%D0\%B8\%D0\% B1\%D1\%83\%D1\%86\%D1\%96\%D1\%97.pdf (дата звернення: 29.05.2020).

40 Directive 2001/83/EC of the European Parliament and of the Council of 6 November 2001 on the Community code relating to medicinal products for human use. URL: https://eur-lex.europa.eu/legalcontent/en/ALL/?uri=CELEX\%3A32001L0083 (дата звернення: 29.05.2020).

41 Державна служба України 3 лікарських засобів та контролю за наркотиками (Держлікслужба) : офіційний сайт. URL: http://dls.gov.ua/ (дата звернення: 29.05.2020).

42 Державний експертний центр MO3 України : офіційний сайт. URL:https://dec.gov.ua/ (дата звернення: 29.05.2020).

43 Міністерство охорони здоров'я України (MO3) : офіційний сайт. URL: https://moz.gov.ua/proministerstvo (дата звернення: 29.05.2020).
} 
1) забезпечення формування та реалізації державної політики у сфері створення, виробництва, контролю якості та реалізації лікарських засобів, медичних імунобіологічних препаратів і медичних виробів, розроблення, погодження, затвердження нормативно-правових актів із цих питань;

2) визначення перспектив та пріоритетних напрямів розвитку сфер створення, виробництва, контролю якості та реалізації лікарських засобів, медичних імунобіологічних препаратів і медичних виробів;

3) затвердження державних і галузевих стандартів, вимог, інструкцій, методів та методик, форм, бланків, переліків лікарських засобів, мінімального асортименту лікарських засобів в аптеках, змін оптововідпускних цін, правил, порядків (здійснення контролю ліцензійних умов, інспектування суб'єктів господарювання, видачі реєстраційних посвідчень, заборони і вилучення з обігу ліків, здійснення моніторингу безпечності ліків у лікувально-профілактичних закладах, проведення різноманітних експертиз) тощо;

4) здійснення державної реєстрації (перереєстрації) лікарських засобів, зокрема й медичних імунобіологічних препаратів в Україні, видача реєстраційного посвідчення на лікарський засіб, ведення Державного реєстру лікарських засобів;

5) надання дозволу на ввезення незареєстрованих в Україні лікарських засобів;

6) ухвалення рішення про затвердження програми клінічних випробувань лікарських засобів та їх проведення.

Щодо державного контролю за ціноутворенням на ринку, то в України було ухвалено такі документи, як:

- постанови Кабінету Міністрів України: «Про заходи щодо стабілізації цін на лікарські засоби» від 17 жовтня 2008 р. № $955^{44}$ (у якій закріплено граничні постачальницько-збутова та торговельна надбавки для різних видів лікарських засобів від 10 та 25\%); «Питання декларування зміни оптово-відпускних цін на лікарські засоби» від 2 липня 2014 р. № $240^{45}$; «Про державне регулювання цін на лікарські засоби» від 9 листопада 2016 p. № $862^{46}$ та ін.;

\footnotetext{
${ }^{44}$ Про заходи щодо стабілізації цін на лікарські засоби : постанова Кабінету Міністрів України від 17 жовтня 2008 р. № 955. URL: https://zakon.rada.gov.ua/laws/show/955-2008-\%D0\%BF (дата звернення: 29.05.2020).

45 Питання декларування зміни оптово-відпускних цін на лікарські засоби : постанова Кабінету Міністрів України від 2 липня 2014 р. № 240. URL: https://zakon.rada.gov.ua/laws/show/240-2014-\%D0\%BF (дата звернення: 29.05.2020).

${ }^{46}$ Про державне регулювання цін на лікарські засоби : постанова Кабінету Міністрів України від 9 листопада 2016 р. № 862. URL: https://zakon.rada.gov.ua/laws/show/862-2016-\%D0\%BF (дата звернення: 29.05.2020).
} 
- накази МОЗ України: «Про затвердження Реєстру граничних оптововідпускних цін на лікарські засоби станом на 22 квітня 2020 р.» від 24 квітня 2020 р. № $957^{47}$; «Про затвердження Реєстру референтних цін (цін відшкодування) на препарати інсуліну станом на 1 лютого 2020 р.» від 17 березня 2020 р. № $668^{48}$; «Про затвердження Реєстру граничних оптововідпускних цін на деякі лікарські засоби, що закуповуються за бюджетні кошти, станом на 3 лютого 2020 р.» від 24 лютого 2020 р. № $508^{49}$ тощо.

Порядок здійснення державного контролю якості лікарських засобів, що ввозяться в Україну, затверджено постановою Кабінету Міністрів України від 14 вересня 2005 р. № $902^{50}$. Зокрема, з метою подальшої реалізації (торгівлі) лікарських засобів, що ввозяться на територію України, або використання їх у виробництві, протягом п'яти робочих днів після закінчення митного оформлення вантажу з лікарськими засобами суб'єкт господарювання подає органові державного контролю за місцем провадження господарської діяльності заяву про видачу висновку про якість ввезених лікарських засобів за формою, встановленою Держлікслужбою. Державний контроль здійснюється шляхом проведення органами державного контролю:

- експертизи поданих суб'єктом господарювання документів (включає перевірку заяви про видачу висновку на відповідність формі й комплектності документів, що додаються до заяви);

- перевірки вантажу за місцем його розташування на відповідність митній декларації щодо кількості лікарських засобів кожної серії;

- здійснення візуального контролю кожної серії лікарських засобів; лабораторного аналізу у визначених Порядком випадках.

Отже, учасники фармацевтичного ринку переважно працюють із двома регуляторними органами в Україні: МO3 відповідає за державну

\footnotetext{
47 Про затвердження Реєстру граничних оптово-відпускних цін на лікарські засоби станом на 22 квітня 2020 р. : наказ MO3 України від 24 квітня 2020 p. № 957. URL: https://moz.gov.ua/ article/ministry-mandates/nakaz-moz-ukraini-vid-24042020--957-pro-zatverdzhennja-reestru-granichnih-optovovidpusknih-cin-na-likarski-zasobi-stanom-na-22-kvitnja-2020-roku (дата звернення: 29.05.2020).

${ }^{48}$ Про затвердження Реєстру референтних цін (цін відшкодування) на препарати інсуліну станом на 1 лютого 2020 p. : наказ МO3 України від 17 березня 2020 p. № 668 . URL: https://moz.gov.ua/article/ministry-mandates/nakaz-moz-ukraini-vid-17032020--668-pro-zatverdzhennja-reestrureferentnih-cin-cin-vidshkoduva nnja-na-preparati-insulinu-stanom-na-01-ljutogo-2020-roku (дата звернення: 29.05.2020).

${ }^{49}$ Про затвердження Реєстру граничних оптово-відпускних цін на деякі лікарські засоби, що закуповуються за бюджетні кошти, станом на 3 лютого 2020 р. : наказ МОЗ України від 24 лютого 2020 p. № 508. URL: https://moz.gov.ua/article/ministry-mandates/nakaz-moz-ukraini-vid-24022020--508-prozatverdzhennja-reestru-granichnih-optovo-vidpusknih-cin-na-dejaki-likarski-zasobi-scho-zakupovujutsja-zabjudzhetni-koshti-stanom-na-03-ljutogo-2020-roku (дата звернення: 29.05.2020).

50 Про затвердження Порядку здійснення державного контролю якості лікарських засобів, що ввозяться в Україну : постанова Кабінету Міністрів України від 14 вересня 2005 р. № 902. URL: http://zakon3.rada.gov.ua/laws/show/902-2005-\%D0\%BF (дата звернення: 29.05.2020).
} 
реєстрацію лікарських засобів, тоді як Держлікслужба займається ліцензуванням, оцінкою дотримання належної виробничої практики (GMP), контролю за якістю лікарських засобів та регулюванням медичних пристроїв.

Можна стверджувати, що створено певні організаційно-правові перепони щодо потрапляння лікарських засобів на ринок України. Відповідно до світового досвіду немає необхідності додатково контролювати лікарський засіб під час процедури реєстрації, тому що він пройшов процедуру клінічних випробувань та підтвердив свою якість і ефективність. У світовій практиці не існує процедури додаткового підтвердження сертифікатів GMP, як в Україні, що значно пришвидшує процес потрапляння лікарського засобу до обігу. Не існує у світовій практиці i процедури додаткового Державного контролю лікарських засобів, які вже неодноразово імпортувалися на територію певної країни та поставлялися в аптеки. Позбувшись додаткового державного контролю імпорту та перейнявши світовий досвід, ми зможемо забезпечити населення України якісними лікарськими засобами в необхідній кількості i, можливо, за доступними цінами.

Питання щодо забезпечення населення якісними та безпечними лікарськими засобами залишається одним із пріоритетних напрямів діяльності держави в особі Міністерства охорони здоров'я України та Державної служби України з лікарських засобів. Тому можна зауважити, що вступ Державної служби України з лікарських засобів та контролю за наркотиками до PIS/C є дуже важливим кроком для забезпечення гарантії того, що в обігу на території України перебувають лікарські засоби, які вироблені й імпортуються відповідно до вимог належної виробничої та торговельної практики, що забезпечує якість лікарських засобів під час їх розроблення, виробництва, транспортування, зберігання, розподілу та контролю на кожному етапі, що гарантує їхню відповідність сучасним вимогам щодо безпеки, якості й ефективності.

\section{ВИСНОВКИ}

Характерною рисою сучасного світового співтовариства є глобалізація (зокрема, регіоналізація) міжнародних економічних, зокрема торговельних, зв'язків. Лікарські препарати становлять особливу групу непродовольчих товарів, що мають забезпечувати/сприяти здорове/ому і повноцінне/ному життю людини, а також мають лікувально-гігієнічне призначення. Лікарські засоби - це товари, на жаль, повсякденного вжитку, без яких важко уявити сучасне, безпечне і повноцінне життя людства. За часів незалежності України, у процесі формування національного ринку лікарських засобів, 
3'явилася значна кількість виробників та імпортерів лікарських препаратів, що впевнено розширюють бізнес і зацікавлені в поліпшенні вітчизняного виробництва, підвищенні конкурентоспроможності української фармацевтичної продукції, з одного боку, а 3 іншого - задоволенні очікувань національних споживачів у безпечному, якісному, доступному й ефективному продукті / товарі. А отже, виникла потреба і в узгодженні (уніфікація, гармонізація, адаптація) організаційно-правового регулювання фармацевтичного ринку, зокрема лікарських засобів, як на національному, так і на міжнародному (передусім на регіональному) рівнях.

Підвищення рівня охорони здоров'я населення з одночасним спрощенням галузевого регулювання, схоже, $\epsilon$ однією 3 найдавніших тенденцій на українському фармацевтичному ринку. У зв'язку із цим Україна перебуває у процесі формування, сподіваємося, ефективного спеціального організаційноправового механізму забезпечення внутрішнього i зовнішнього обігу лікарських засобів, що має приводити до зменшення адміністративнофінансового тягаря (для суб'єктів господарювання та фізичних осіб як кінцевих споживачів лікарських засобів) та більш ефективних регуляторних підходів (інструментів) у даному питанні. Ще одним акцентом $\epsilon$ впорядкування вітчизняного фармацевтичного регулювання 3 міжнародно визнаними стандартами, зокрема стандартами ЄС.

\section{АНОТАЦІЯ}

Праця присвячена висвітленню стану й особливостей організаційноправового забезпечення та регулювання державами зовнішньої та внутрішньої торгівлі лікарськими засобами на міжнародному регіональному рівні (у рамках Європейського Союзу та зобов'язань 3 Угоди про асоціацію між Україною та Свропейським Союзом 2014 року) та національному рівні (на прикладі України й інших країнах світу, зокрема держав-членів Європейського Союзу). Актуальність теми визначається процесом реформування діяльності регуляторних органів у сфері міжнародного та внутрішньодержавного обігу лікарських засобів. Одним із завдань організаційно-правової складової частини механізму ефективного, дієвого і необтяжливого регулювання обігу фармацевтичного ринку $\epsilon$ створення уніфікованих та прозорих правил щодо імпорту/експорту лікарських засобів, орієнтованих на загальноприйняті міжнародні норми і стандарти. Основна уваги приділена інституціям і нормативно-правовим актам Свропейського Союзу й України щодо різних аспектів реалізації регуляторної (організаційно-правової) політики держав щодо обігу лікарських засобів, зокрема їх: розробки, виробництва, внутрішнього і зовнішнього торговельного обігу, реєстрації (можливості 
наявності на ринку), сертифікації якості (як виробництва, так і якості товару), ліцензування (як виду господарської діяльності та як товару, що переміщується через митні кордони держав), безпечності та якості всіх етапах обігу (фармакологічний державний нагляд / контроль), доступності (наприклад, цінової) тощо.

\section{ЛІТЕРАТУРА}

1. Господарський кодекс України : Закон від 16 січня 2003 р. № 436-IV. URL: https://zakon.rada.gov.ua/laws/show/436-15 (дата звернення: 29.05.2020).

2. Державна Служба України 3 лікарських засобів та контролю за наркотиками (Держлікслужба) : офіційний сайт. URL: http://dls.gov.ua/ (дата звернення: 29.05.2020).

3. Державний експертний центр MO3 України : офіційний сайт. URL: https://dec.gov.ua/(дата звернення: 29.05.2020).

4. Свропейське агентство 3 лікарських засобів (European Medicines Agency, EMA) : офіційний сайт. URL: https://www.ema.europa.eu/en (дата звернення: 29.05.2020).

5. Свропейський директорат 3 якості лікарських засобів та охорони здоров'я (European Directorate for the Quality of Medicines \& Health Care, EDQM) : офіційний сайт. URL: https://www.edqm.eu/ (дата звернення: 29.05.2020).

6. Лікарські засоби. Належна практика дистрибуції. СТ-Н МОЗУ 42-5.0: 2014 : настанова МО3 України. Стандарт. Київ : Міністерство охорони здоров'я України, 2014. 51 c. URL: http://dls.gov.ua/wp-content/uploads/2019/ 06/\%D0\%9D\%D0\%B0\%D0\%BB\%D0\%B5\%D0\%B6\%D0\%BD\%D0\%B0-\%D0 \%BF\%D1\%80\%D0\%B0\%D0\%BA\%D1\%82\%D0\%B8\%D0\%BA\%D0\%B-\%D0 $\% \mathrm{~B} 4 \% \mathrm{D} 0 \% \mathrm{~B} 8 \% \mathrm{D} 1 \% 81 \% \mathrm{D} 1 \% 82 \% \mathrm{D} 1 \% 80 \% \mathrm{D} 0 \% \mathrm{~B} 8 \% \mathrm{D} 0 \% \mathrm{~B} 1 \% \mathrm{D} 1 \% 83 \% \mathrm{D} 1$ $\% 86 \% \mathrm{D} 1 \% 96 \% \mathrm{D} 1 \% 97 . p d f$ (дата звернення: 29.05.2020).

7. Мережа офіційних лабораторій з контролю за лікарськими засобами (Network of official medicines control laboratories, OMCLs). URL: https://www.edqm.eu/sites/default/files/brochure_omcl_double_page_web.pdf (дата звернення: 29.05.2020).

8. Міжнародна система співробітництва фармацевтичних інспекцій (Pharmaceutical Inspection Cooperation Scheme, PIC/S) : офіційний сайт. URL: https://www.picscheme.org/en/members?paysselect=UA (дата звернення: 29.05.2020).

9. Міжнародна система співробітництва фармацевтичних інспекцій (Pharmaceutical Inspection Cooperation Scheme, PIC/S) : офіційний сайт. URL: https://www.picscheme.org/en/members (дата звернення: 29.05.2020). 
10. Міністерство охорони здоров'я України (МО3) : офіційний сайт. URL: https://moz.gov.ua/pro-ministerstvo (дата звернення: 29.05.2020).

11. Питання декларування зміни оптово-відпускних цін на лікарські засоби : постанова Кабінету Міністрів України від 2 липня 2014 р. № 240. URL: https://zakon.rada.gov.ua/laws/show/240-2014-\%D0\%BF (дата звернення: 29.05.2020).

12. Податковий кодекс України від 2 грудня 2010 р. № 2755-VI. URL: https://zakon.rada.gov.ua/laws/show/2755-17 (дата звернення: 29.05.2020).

13. Про державне регулювання цін на лікарські засоби : постанова Кабінету Міністрів України від 9 листопада 2016 р. № 862. URL: https://zakon.rada.gov.ua/laws/show/862-2016-\%D0\%BF (дата звернення: 29.05.2020).

14. Про Державний бюджет України на 2020 р. : Закон України від 14 листопада 2019 р. № 294-IX. URL: https://zakon.rada.gov.ua/laws/show/ 294-20 (дата звернення: 29.05.2020).

15. Про затвердження Ліцензійних умов провадження господарської діяльності з виробництва лікарських засобів, оптової та роздрібної торгівлі лікарськими засобами, імпорту лікарських засобів (крім активних фармацевтичних інгредієнтів) : постанова Кабінету Міністрів України від 30 листопада 2016 р. № 929. URL: http://zakon.rada.gov.ua/laws/show/9292016-\%D0\%BF (дата звернення: 29.05.2020).

16. Про затвердження Положення про Міністерство охорони здоров'я України : постанова Кабінету Міністрів України від 25 березня 2015 р. № 267. URL: https://zakon.rada.gov.ua/laws/show/267-2015-\%D0\%BF (дата звернення: 29.05.2020).

17. Про затвердження Порядку встановлення заборони (тимчасової заборони) та поновлення обігу лікарських засобів на території України : наказ MO3 України від 22 листпоада 2011 p. № 809. URL: https://zakon.rada.gov.ua/laws/show/z0126-12 (дата звернення: 29.05.2020).

18. Про затвердження Порядку державної реєстрації (перереєстрації) лікарських засобів і розмірів збору за їх державну реєстрацію (перереєстрацію) : постанова Кабінету Міністрів України від 26 травня 2005 p. № 376. URL: https://zakon.rada.gov.ua/laws/show/376-2005-\%D0\%BF (дата звернення: 29.05.2020).

19. Про затвердження Порядку здійснення державного контролю якості лікарських засобів, що ввозяться в Україну : постанова Кабінету Міністрів України від 14 вересня 2005 р. № 902. URL: http://zakon3.rada.gov.ua/ laws/show/902-2005-\%D0\%BF (дата звернення: 29.05.2020).

20. Про затвердження Порядку проведення експертизи реєстраційних матеріалів на лікарські засоби, що подаються на державну реєстрацію 
(перереєстрацію), а також експертизи матеріалів про внесення змін до реєстраційних матеріалів протягом дії реєстраційного посвідчення : наказ MO3 України від 26 серпня 2005 р. № 426. URL: https://zakon.rada.gov.ua/ laws/show/z1069-05 (дата звернення: 29.05.2020).

21. Про затвердження Порядку проведення підтвердження відповідності умов виробництва лікарських засобів вимогам належної виробничої практики : наказ МO3 України від 27 грудня 2012 р. № 1130. URL: https://zakon.rada.gov.ua/laws/show/z0133-13 (дата звернення: 29.05.2020).

22. Про затвердження Реєстру граничних оптово-відпускних цін на деякі лікарські засоби, що закуповуються за бюджетні кошти, станом на 3 лютого 2020 р. : наказ MO3 України від 24 лютого 2020 р. № 508. URL: https://moz.gov.ua/article/ministry-mandates/nakaz-moz-ukraini-vid-24022020-508-pro-zatverdzhennja-reestru-granichnih-optovo-vidpusknih-cin-na-dejakilikarski-zasobi-scho-zakupovujutsja-za-bjudzhetni-koshti-stanom-na-03-ljutogo2020-roku (дата звернення: 29.05.2020).

23. Про затвердження Реєстру граничних оптово-відпускних цін на лікарські засоби станом на 22 квітня 2020 р. : наказ МОЗ України від 24 квітня 2020 p. № 957. URL: https://moz.gov.ua/article/ministrymandates/nakaz-moz-ukraini-vid-24042020--957-pro-zatverdzhennja-reestrugranichnih-optovo-vidpusknih-cin-na-likarski-zasobi-stanom-na-22-kvitnja2020-roku (дата звернення: 29.05.2020).

24. Про затвердження Реєстру референтних цін (цін відшкодування) на препарати інсуліну станом на 1 лютого 2020 р. : наказ MO3 України від 17 березня 2020 p. № 668. URL: https://moz.gov.ua/article/ministrymandates/nakaz-moz-ukraini-vid-17032020--668-pro-zatverdzhennja-reestrureferentnih-cin-cin-vidshkoduvannja-na-preparati-insulinu-stanom-na-01ljutogo-2020-roku (дата звернення: 29.05.2020).

25. Про заходи щодо стабілізації цін на лікарські засоби : постанова Кабінету Міністрів України від 17 жовтня 2008 р. № 955. URL: https://zakon.rada.gov.ua/laws/show/955-2008-\%D0\%BF (дата звернення: 29.05.2020).

26. Про лікарські засоби : Закон України від 4 квітня 1996 р. № 123/96BP. URL: https://zakon.rada.gov.ua/laws/show/123/96-\%D0\%B2\%D1\%80 (дата звернення: 29.05.2020).

27. Про ліцензування видів господарської діяльності : Закон України від 2 березня 2015 р. № 222-VIII. URL: https://zakon.rada.gov.ua/laws/ show/222-19 (дата звернення: 29.05.2020).

28. Угода про асоціацію між Україною, 3 однієї сторони, та Європейським Союзом, Свропейським співтовариством з атомної енергії і 
їхніми державами-членами, з іншої сторони, від 27 червня 2014 р. URL: http://zakon2.rada.gov.ua/laws/show/984_a11 (дата звернення: 29.05.2020).

29. Case C-297/15: Request for a preliminary ruling from the Sø- og Handelsretten (Denmark) lodged on 18 June 2015 - Ferring Lægemidler A/S, acting on behalf of Ferring B.V. v. Orifarm A/S. URL: https://eur-lex.europa.eu/legal-content/EN/TXT/?uri=CELEX:62015CN0297 (дата звернення: 29.05.2020).

30. Commission Communication on parallel imports of proprietary medicinal products for which marketing authorisations have already been granted: Commission of the European Communities of 30.12.2003 COM(2003) 839 final, Brussels, (COM (2003) 839). URL: https://ec.europa.eu/health/ sites/health/files/files/eudralex/vol-1/com_2003_839/com_2003_839_en.pdf (дата звернення: 29.05.2020).

31. Commission Directive 2005/28/EC of 8 April 2005 laying down principles and detailed guidelines for good clinical practice as regards investigational medicinal products for human use, as well as the requirements for authorisation of the manufacturing or importation of such products (Text with EEA relevance). URL: https://eur-lex.europa.eu/legal-content/ EN/ALL/?uri=CELEX\%3A32005L0028 (дата звернення: 29.05.2020).

32. Directive 2001/20/EC of the European Parliament and of the Council of 4 April 2001 on the approximation of the laws, regulations and administrative

33. Provisions of the Member States relating to the implementation of good clinical practice in the conduct of clinical trials on medicinal products for human use. URL: eur-lex.europa.eu/legal-content/EN/TXT/?uri=CELEX\%3A32001L 0020 (дата звернення: 29.05.2020).

34. Directive 2001/83/EC of the European Parliament and of the Council of 6 November 2001 on the Community code relating to medicinal products for human use. URL: https://eur-lex.europa.eu/legal-content/en/ALL/?uri=CELEX \%3A32001L0083 (дата звернення: 29.05.2020).

35. Heads of Medicines Agencies (HMA): Official website. URL: https://www.hma.eu/ (дата звернення: 29.05.2020).

36. IMS. World Review 2014. URL: https://www.reportlinker.com/ p01593816/IMS-World-Review-Executive.html (дата звернення: 29.05.2020).

37. Regulation (EC) No 726/2004 of the European Parliament and of the Council of 31 March 2004 laying down Community procedures for the authorisation and supervision of medicinal products for human and veterinary use and establishing a European Medicines Agency (Text with EEA relevance). URL: https://eur-lex.europa.eu/legal-content/EN/TXT/?uri=CELEX\%3A32004 R0726 (дата звернення: 29.05.2020). 
38. Regulation (EU) $2015 / 755$ of the European Parliament and of the Council of 29 April 2015 on common rules for imports from certain third countries. URL: https://eur-lex.europa.eu/legal-content/en/TXT/?uri=CELEX: 32015R0755 (дата звернення: 29.05.2020).

Information about author:

Holubieva V. O.,

Ph. D., Associate Professor,

Professor at the Department of International and European Law Kyiv National Economic University named after Vadym Hetman 54/1, Prospect Peremogy, Kyiv, 03057, Ukraine 